Viktoriia CHUIENKO, orcid.org/0000-0003-0494-3463 Senior Lecturer at the Department of the English language Petro Mohyla Black Sea National University (Mykolyiv, Ukraine) victoria.chuenko@ukr.net

\title{
WAYS OF DEVELOPING KEY SUSTAINABILITY COMPETENCIES OF UNIVERSITY STUDENTS AT FOREIGN LANGUAGE CLASSES
}

Sustainable development is a new vision of interaction between the society and the environment, a shift in the system of values for the sake of creating a balanced sustainable future, a goal which is pursued by many countries in the world. The implementation of SD ideas and values is done by means of education, at all levels, including the higher education, and is aimed at developing key sustainability competencies, including systems thinking, anticipatory, strategic, collaborative, problem-solving ones. The article states that this objective can be achieved within a university environment, while teaching a foreign language for specific purposes.

The author presents some ideas of how to increase students'sustainability awareness and master their sustainability competencies at foreign language classes when they tackle real-world problems and interact in the professionallyoriented situations. The goals, content, forms and learning methods of foreign language for specific purposes training are specified in the context of ESD. The research demonstrates the efficiency of promoting ESD ideas with the help of incorporating communicative-activity and problem-based approaches into the foreign language training. Implementing interdisciplinary knowledge is proved to be beneficial.

The author shares her experience of teaching ESD values while discussing sustainability-related issues with students of different specialties, emphasizing the importance of doing this for the sake of raising sustainable citizens who are able to value and understand interrelation of the things that surround them, to take responsibility for their actions and anticipate the consequences of their future professional activity.

Key words: ESD, sustainability competencies, a foreign language for specific purposes, communicative-activity, problem-based approaches, interdisciplinary.

Вікторія ЧУСНКО, orcid.org/0000-0003-0494-3463 старший викладач кафедри англійської мови Чорноморського начіонального університету імені Петра Могили (Миколаїв, Україна) victoria.chuenko@ukr.net

\section{ШЛЯХИ ФОРМУВАННЯ КОМПЕТЕНЦЙ ДЛЯ СТАЛОГО РОЗВИТКУ ПІД ЧАС ВИВЧЕННЯ ІНОЗЕМНОЇ МОВИ ЗА ПРОФЕСІЙНИМ СПРЯМУВАННЯМ}

Сталий розвиток-нове бачення взаємодї суспільства й навколишнього середовища, зміна иіннісних орієнтирів заради створення збалансованого майбутнього, важлива концепція, якою керується сьогодні більшість краӥн світу. Імплементація ї̈ ідей і иінностей відбувається через систему освіти, на всіх ї̈ рівнях, включаючи вищу освіту, i націлена на розвиток системного мислення, випереджувальної, стратегічної, міжособистісної компетенцій, вміння вирішувати проблеми тощо. Людина, яка володіє ичими ключовими компетенціями, має розвинене мислення, здатна критично оцінювати й виявляти причинно-наслідкові зв'язки, вирішувати складні питання, прогнозувати наслідки власної професійної діяльності та брати на себе відповідальність за скоєні дії. У статті стверджується, щзо всі ијі компетенції можуть бути сформовані в університетському середовищі під час вивчення іноземної мови за професійним спрямуванням.

Автором представлені ідеї щуодо підвищення рівня мотивачії та свідомості в студентів щзодо сталого розвитку, коли вони вирішують питання професійного характеру та спілкуються, обмінюючись знаннями й досвідом у ситуаціях, наближених до реальних. У статті визначаються цілі, зміст, форми та методи навчання іноземної мови для досягнення спецііальних иілей у контексті освіти для сталого розвитку. Для формування та вдосконалення компетенцій, необхідних для забезпечення сталого розвитку, вказується на дочільність використання комунікативно-діяльнісного та проблемного підходів, а також залучення міждисииплінарних зв'язків. Наголошено на тому, що формування системи ціннісних оріснтирів через обговорення тем, які стосуються взаємодії суспільства й навколишнього світу, має відбуватися на заняттях з іноземної мови на всіх спеціальностях і відображатися в навчальних програмах.

Ключові слова: освіта для сталого розвитку, компетенції для сталого розвитку, іноземна мова за професійним спрямуванням, комунікативно-діяльнісний підхід, проблемне навчання, міждисциплінарні зв'язки. 
Problem statement. Education for Sustainable Development (ESD) was and is still believed to be a new vision of education that encourages people to take responsibility for creating a balanced sustainable future. The emphasis here is made on reevaluation of their goals, habits, values and attitudes towards the surrounding world in favor of a sustainable development planning and a so-called responsible consumption. The educational and behavioral models are shifted from getting knowledge about the environment to nurturing value-based attitude to it, from taking immediate decisions to anticipating the consequences of the actions taken.

Back in 2005, UNESCO, emphasizing that education was one of the key tools of shaping values necessary for attaining sustainable development, announced the United Nations Decade of Education for Sustainable Development (2005-2014). Later on, in 2015, the UN members adopted the 2030 Agenda for Sustainable Development that includes 17 goals (SDGs) aimed to spur economic and social growth, improve health sector, the sphere of production and education. Its Goal 4 clearly reflects the urgency to integrate ESD principles into all levels of education, including higher education, and develop key competencies essential to become sustainable citizens who will support and implement sustainability ideas on local and global scales.

Research analysis. Education for Sustainable Development (ESD) is a lifelong process which should be started in childhood and can be incorporated in school or university life, taking into account age, socio-psychological and axiological peculiarities of learners. Being one of the priorities of contemporary higher education in Ukraine, ESD mainly involves "greening" and humanization of education, focusing much attention on forming sustainable-earth mentality, ecological culture and ethics of university students as an essential prerequisite for promoting sustainable development principles and ideas. With this kind of mentality, students regard themselves as a part of a natural community, follow ethical rules and think about possible ways of their coexistence with nature not only for the present benefits, but also for the future outcomes. However, ESD is not limited to an environmental component; it involves social and economic ones, which are all interdependent (Tetiana, Malolitneva, 2020).

The list of key sustainability competencies has been defined as the following (A. Wiek, L. Withycombe, C. Redman, 2011):

- systems thinking competency which involves the ability to analyze problems and apply systems concepts;
- normative competency which involves the knowledge of basic norms of sustainable development, its targets, principles and ideas;

- anticipatory competency which is seen as the ability to think critically, to forecast, to assess the future results and consequences of the actions taken, to weigh possible benefits and limitations, considering alternative ways;

- strategic thinking competency which means the ability to plan, model and overcome obstacles to reach the desired outcomes;

- collaborative or interpersonal competency (foresees the ability to exchange knowledge and skills and learn from the experience of others, to negotiate and deal with conflicts, to seek for compromise and mutually participate in problem-solving);

- integrated problem-solving competency is the ability to analyze, systematize, conduct research, evaluate and develop a reasonable solution.

There are various mechanisms of integrating SD principles into the educational context and developing the above-mentioned competencies. To make this process more efficient, some experts emphasize the necessity of strengthening school and university language curriculum with more ESD content (Babanoglu, Agcam, 2020) or employing an action-oriented transformative pedagogy, providing teachers with special training to facilitate ESD (Rieckman, 2018). With its numerous learning strategies and tools, foreign language learning has a wide range of possibilities to achieve this objective. Y. Lavrysh and I. Lytovchenko mention that by introducing projectand place-based approaches into English classes it is possible to increase students' sustainability awareness and general motivation to learning (Lavrysh, I. Lytovchenko, 2019).

The aim of the article is to analyze the ways of mastering/activating sustainability competencies of university students while learning/teaching a foreign language for specific purposes, with the inclusion of environmental, social and axiological components into the learning process at the university, in particular at Ecology department at Petro Mohyla Black Sea National University.

Presentation main material. In the context of ESD, teaching students a foreign language for specific purposes can be viewed as a specially organized process where the orientation of the goals, content, forms and methods of instruction is aimed not only at the future specialty of students and developing their professional qualities, but also at forming their communicative competence with a responsible attitude to the natural and social environment in the process of solving mental and cognitive tasks. 
Thus, the goal of a foreign language for specific purposes in the context of ESD is to shape the personality of a student who is able and willing to participate in communication in professional, sustainability-related situations, using a foreign language. The pragmatic aspect of the goal of learning is associated with developing students' communicative competence for using a foreign language in professional, sustainability-related situations. The cognitive aspect is seen in shaping students' individual picture of the world, moving towards sustainable development, and using a foreign language as a tool for learning about this world. The educational aspect is responsible for the formation of the students' emotional and axiological attitudes towards nature and the environment, their ability and desire to perceive and tolerate the opinions and attitudes of other people, of other cultures, which forms the basis for intercultural communication and stimulates their readiness to participate in it.

In addition to the most important general pedagogical principles of foreign language education (which involve the principle of personality-oriented education; consciousness; the principle of activity in training), within the framework of ESD, attention should be paid to the implementation of such principles as tolerance to different viewpoints and the possibility of developing one's own position based on critical thinking skills; prediction as a vision of not only the past and the present problems, but also the future ones; activation of self-study and autonomous activity of students in order to obtain the final educational results.

For teaching university students a foreign language for specific purposes within the framework of ESD, the following complex pedagogical conditions must be met:

1) creating a contextual environment in the framework of a professionally-oriented foreign language and integrating competence, problem and axiological approaches to learning;

2) providing advanced and differentiated education in the formation of foreign language training content;

3 ) the cooperation of local, regional and global aspects in education.

The content of the professionally-oriented foreign language training in the context of ESD, in addition to the traditional constituents (knowledge, skills/competencies), must also include an emotional and evaluative one. It will not only influence the formation of positive values while studying a foreign language and doing activities related to language acquisition, but it will also enhance students' motivation to obtain and perceive the information about the environment and to discuss it in professionally-oriented communication situations in class. The subject component of the content should include lexical material (professional and sustainability-related terms and concepts), linguistic and cultural knowledge, environmental knowledge, communicative goals and intentions, professional sustainability-related texts, themes and situations. The procedural component of the content of training should include the skills and abilities of oral and written communication in a foreign language in professional situations related to the problems of the environment and sustainability on the whole. The emotional-evaluative component of the content of training includes emotional activities connected with analyzing and evaluating personal experience and contribution while dealing with environmental issues/cases and its subsequent discussion in the class using a foreign language, or while debating at conferences and seminars.

Teaching a foreign language for specific purposes in the context of ESD, in our opinion, requires the use of communicative-activity and problem-based approaches. The communicative-activity approach foresees the simultaneous development of all speech skills and abilities of learners engaged in the process of learning which models real communication. They learn by practicing, by interacting and collaborating with each other while accomplishing different professionally-oriented or sustainabilityrelated tasks.

In the problem-based approach, the attention is focused on considering a real-world sustainability problem and problem situation of moral or spiritual value that must motivate students to get a deeper understanding of the target concept(s), to investigate the solutions they come across in various learning resources, to anticipate the results, to make a reasoned decision of their own, and finally to defend it either independently or in a team.

The problems can be borrowed from a variety of sources: authentic books or magazines, movies or YouTube videos. In search for ideas, interdisciplinary knowledge is valuable. The sustainability-related topics (included into the language curriculum) may encompass anthropogenic global disasters, climate change, wars and poverty, pandemic, technological development and security, alternative sources of energy, etc. The chosen material should have:

- high cognitive value (more often, it should be informative and professionally-oriented, containing plenty of facts, terms, abbreviations, peculiar to the target area of knowledge);

- an element of novelty, which is likely to provoke certain interest to the topic studied; 
- implicitly or explicitly expressed information, including moral and value-related nature, with some contradictions;

- a convincing element - the author's influence on the learner's emotional state through numerous facts, figures, proofs, vivid examples, etc. that sometimes can be even provocative.

We believe language training in the context of ESD must be conducted in a modular format, each structural component of which is a unit with a problem situation and a number of lexical and grammatical exercises to support it. Combining learning materials with one central connecting idea allows creating a substantive thematic community within one unit, which can even serve as a junction with neighboring units. The learners are supposed to focus their attention more on problem situation analysis and its solution than on mere reading texts and doing text-related exercises. A textbook is seen as a source of information, rather than the source of the solution (Steinemann, 2003: 218).

When the messages expressed by the students while engaging with the assigned problem are confusing and difficult to understand, the teacher can apply to clarification-seeking techniques, which as a rule involve non-judgmental questioning or summarizing. Clarification occurs through:

1) the questions asked by the teacher to support the discussion: "What choices can be made in this situation and what is your decision? What are the possible consequences of your choice? What wouldn't be/ wouldn't happen if ...? Are you satisfied with what you have chosen?";

2) work with the list of adjectives/nouns/synonyms/antonyms/derivatives or the lexical filling of frames;

3) asking for definition of unfamiliar words or explaining the contextual meaning of polysemantic words which, as a rule, convey several concepts, thus becoming misleading for learners (for example, a spring as a season of the year and a water body);

4) explaining the origin of the words (for example, knowing the meaning of the root "terra" ("land or territory") it is possible to guess the meaning of the phrases "extraterrestrial beings" or "terrestrial ecosystems");

5) providing visual means to support verbal expressions;

6) asking for specific examples or sharing personal experience;

7) reflexive discussions, etc.

An example of a problem situation of spiritual and cognitive value can be a discussion offered to the senior students (the $4^{\text {th }}$ course) of Ecology department at Petro Mohyla Black Sea National University about the expediency of constructing a nuclear power station in some region of Ukraine and its consequences for the environment and population on both local and global scales. On the basis of the proposed text containing information about the positive and negative aspects of using nuclear energy (information model), students are to decide a problem situation: they compare the advantages and disadvantages of this type of energy with the other ones (non-renewable - oil, gas, coal, and renewable - hydropower, wind energy, solar energy) and justify their choice. Then they are given the problem situation of a spiritual and moral character based on the film about Chernobyl catastrophe and other accidents at nuclear power plants worldwide (explicitly and implicitly expressed moral value information) to determine the possible risks and benefits of making or not making a decision in favor of building a new nuclear power plant. Students are asked to comment, for example, on economic feasibility, on demographic and environmental threats. As a rule, their opinions vary, so they get invaluable experience in defending their own point of view in a foreign language and feel the necessity to compromise and tolerate another opinion, which they may not agree with. At the same time, students define for themselves the moral and value reference points according to which they will live and work in the future.

What should be noted is that it is vital to develop sustainability competencies and sustainable-earth mentality not only of Ecology students, but also of students of other specialties, no matter whether they study law, economics or computer sciences. This idea is supported by many scientists (Tetiana, Malolitneva, 2020). Thus, the ESP curriculum for Computer engineering students has been improved to include the topics connected with management and advertising strategies, life safety, technological progress and security, recycling and reuse etc. They are offered to conduct project research on "How to dispose of the outdated equipment" or "How green is IT sphere" or to develop a web resource to assist in promoting the ideas of sustainability. Economics students are asked to make start-up business plans and calculate not only economic, but also environmental hazards of a new project or product.

Regardless of which learning techniques for efficient language acquisition the teacher applies to, whether to case studies, role games, debates, infographic presentations or simulations, all of them to a greater or lesser degree allow for a comprehensive check of students' both communication skills and sustainability awareness. Because of the availability of technical resources, graphics and video apps that students nowadays have at their disposal, making 
short video clips/films in teams of 3-4 students has gained much popularity among students. This challenging and creative activity, on the one hand, can promote teamwork and healthy competition when it comes to competing with other teams, making students highly motivated and involved, while on the other hand, it makes them analyze and think more consciously about the problems of the environment and their role in it.

A proactive approach to the selection of the content of foreign language training allows us to shape the conscious and humanistic attitude of students towards their future actions and future professional activity at the initial stage of studying at the university. Students realize that a great number of problems must be tackled systemically, guided not only by the principles of expediency and material benefits, but also taking into account the interests of other people, the consequences for the nature and the planet on the whole. The results of the conducted survey have revealed that $76 \%$ of the students of the experimen- tal group at Ecology specialty and 54\% of Computer engineering students are sure that while conducting their professional activity they will necessarily take into account social and environmental hazards.

Conclusions. To sum up, it should be noted that developing learners' sustainability competencies in the process of foreign language for specific purposes acquisition is done in synergy with developing communication skills and other basic competencies. It is possible to achieve this thanks to incorporating communicative-activity and problem-based approaches, as well as implementing interdisciplinary knowledge in the foreign language training. Moreover, it's vital to introduce and discuss sustainability-related topics with students of all specialties. ESD can promote students' understanding of interdependence and interrelation of professional, economic, environmental and social issues, and teach them to follow the principles of ESD, concerning thinking globally and acting locally, as well as thinking about the future by acting now.

\section{СПИСОК ВИКОРИСТАНИХ ДЖЕРЕЛ}

1. Babanoglu M., Agcam R. Sustainability in compulsory English curricula for primary and secondary education: competencies and components. Academic studies in foreign language education. Livre de Lyon, 2020. P. 38-54.

2. Lavrysh Y., Lytovchenko I. The case of education for sustainable development approaches implementation at English language classes at the technical university in Ukraine. Pedagogy. 2019. Vol. 91 (5). P. 736-749.

3. Rieckman M. Learning to transform the world: key competencies in ESD. Issues and trends in Education for Sustainable Development / ed. by A. Leicht, J. Heiss, Won J. Byun. Ch. 2. UNESCO, 2018. P. 39-59.

4. Steinemann A. Implementing sustainable development through problem-based learning: Pedagogy and practice. Journal of Professional Issues in Engineering Education and Practice. 2003. Vol. 129 (4). P. 216-224.

5. Tetiana H., Malolitneva V. Conceptual and legal framework for promotion of education for sustainable development: case study for Ukraine. European Journal of Sustainable Development. 2020. Vol. 9 (2). P. $42-54$.

6. Transforming our world: the 2030 Agenda for sustainable development. URL: https://sdgs.un.org/2030agenda (date of accessed: 31.01.2021).

7. Wiek A., Withycombe L., Redman C.L. Key competencies in sustainability: a reference framework for academic program development. Sustainability Science. 2011. Vol. 6 (2). P. 203-218.

\section{REFERENCES}

1. Babanoglu, M., Agcam, R. (2020). Sustainability in compulsory English curricula for primary and secondary education: competencies and components. Academic studies in foreign language education, Livre de Lyon, pp. 38-54 [in English].

2. Lavrysh, Y., Lytovchenko, I. (2019). The case of education for sustainable development approaches implementation at English language classes at the technical university in Ukraine. Pedagogy, 91 (5), pp. 736-749 [in English].

3. Rieckman M. (2018). Learning to transform the world: key competencies in ESD. Issues and trends in Education for Sustainable Development, Chapter 2, pp. 39-59 [in English].

4. Steinemann, A. (2003). Implementing sustainable development through problem-based learning: Pedagogy and practice. Journal of Professional Issues in Engineering Education and Practice, 129 (4), pp. 216-224 [in English].

5. Tetiana, H., Malolitneva, V. (2020). Conceptual and legal framework for promotion of education for sustainable development: case study for Ukraine. European Journal of Sustainable Development, 9 (2), pp. $42-54$ [in English].

6. Transforming our world: the 2030 Agenda for sustainable development. URL: https://sdgs.un.org/2030agenda [in English].

7. Wiek, A., Withycombe, L., Redman, C.L. (2011). Key competencies in sustainability: a reference framework for academic program development. Sustainability Science, 6 (2), pp. 203-218 [in English]. 